Educational Research for Social Change (ERSC)

Volume 8 No. 1, April 2019

pp. 138-152

ersc.nmmu.ac.za

ISSN: 2221-4070

\title{
The Map as Object: Working Beyond Bounded Realities and Mapping for Social Change
}

Jayna McQueen Baker

Texas Christian University

j.I.mcqueen@tcu.edu

Gabriel Huddleston

Texas Christian University

g.huddleston@tcu.edu

Erin Atwood

Texas Christian University

e.d.atwood@tcu.edu

\section{Abstract}

Research supports the use of geographic information systems (GIS) to inform and direct action in geography and urban planning. As critical researchers, we also see the power of GIS in participatory projects with students to analyse power, privilege, and oppression in order to move toward action. Understanding that meaning shifts through an interplay of social, linguistic, and material interactions, GIS has the unique ability to show fluidity yet connectedness across geographic borders, providing intriguing opportunities as a research tool. Drawing on recent studies of GIS in research, we recognise the potential to build understanding of spatial context as both socially and politically constructed, but also the tendency to see a map as bounded data in finality. We argue here the importance to return the data back to the material itself in order to avoid reifying a flat, discursive representation of the material without claiming agency. Through the planning of a participatory project with GIS as a research tool, we consider the implications, cautions, and potential of using GIS as a fluid and incomplete representation of a moment in time and space that is also a path moving toward something else.

Keywords: geographic information systems, new materialism, social justice, youth participatory action research (YPAR)

Copyright: (c) 2019 Jayna McQueen Baker, Gabriel Huddleston and Erin Atwood

This is an open access article distributed under the terms of the Creative Commons Attribution NonCommercial License, which permits unrestricted non-commercial use, distribution, and reproduction in any medium, provided the original author and source are credited. 
Please reference as: McQueen Baker, J., Huddleston, G. \& Atwood, E. (2019). The Map as

Object: Working Beyond Bounded Realities and Mapping for Social Change. Educational Research for Social Change, 8(1), 138-152. http://dx.doi.org/10.17159/2221-4070/2018/v8i1a9

\section{Introduction}

Geographic information systems (GIS) have historically been used to plan and monitor physical landscapes and geographic features of communities (Elwood \& Mitchell, 2013; Thatcher, 2013; Wyly et al., 2012). GIS, by definition, is a geographic mapping system via computer or web-based programmes (Smith \& Miller, 2013). GIS users can then use these geographic markings to create maps that both visually represent data and can be easily manipulated and updated. Maps then illustrate layers of data, visually displaying spatial relationships. Evolution of, and increased access to, GIS technology provides an opportunity to visually create and share experiences, information, and perspectives across a broader audience, breaking geographic barriers for users through multimodal construction of meaning. Taking GIS outside the boundaries of traditional uses, critical researchers have begun to see GIS as a research tool honouring the participant as knowledge holder (Elwood \& Mitchell, 2013), seeking to "involve the researched in a democratised process of inquiry characterised by negotiation, reciprocity, empowerment" (Lather, 1986, p. 257). Increased accessibility of technology pushes researchers to consider how these tools might be used in critical scholarship in nontraditional ways. Troubling the concept of map as an object that fixes the spatial as static and unchanging, in this paper we challenge the idea of maps as end products of scientific processes and, instead, see them representing two important aspects of critical research. The first is the continuing, evolving, and democratic relationship between researchers and participants. The second is a representation of the socio-spatial dialectic put forth by the spatial turn (see Soja, 2010). In the former, the map becomes more than an "everyday object" if it comes from a process that is created with participants and for participants. With the latter, researchers consider how the map can better represent the socio-spatial dialectic as outlined by Soja (2010) below:

Critical geographers may claim they accept the basic idea of a socio-spatial dialectic, but nearly all tend nonetheless in their writings to give greater stress to how social processes such as class formation, social stratification, or racist or masculinist practices shape geographies than to how geographies actively affect these social processes and forms. (p. 4)

Understanding that meaning shifts and changes through an interplay of social, linguistic, and material interactions (Barad, 2003; Deleuze \& Guattari, 2014), technologies like GIS, have the unique ability to show fluidity yet connectedness across geographic borders. Furthermore, GIS provides intriguing opportunities to value the input of students in research projects. These research projects, defined here as youth participatory action research (YPAR), can use GIS as a tool for students to document and analyse their own experiences, geographically. With that in mind, we set out to explore GIS as a tool in our own work with YPAR. However, this paper is less about the data collected in this ongoing research project, and more about how our initial vision for the use of GIS has shifted throughout the research project. In the paper, we analyse this shifting use of GIS and its potential imposition on, and usefulness to, the participants based on critical feedback from participants and critical geographic scholars, and our own self-reflections.

Like a river, our research came from someplace prior to where we stand now. It is influenced by and influences what it encounters, embraces, and transforms and continues to travel someplace else. Using the river as a metaphor to guide our analysis, we first describe where we are at in the research. Then 
we develop three important ideas: the literature and research plan prior to implementation, the disruptions during implementation, and the still incomplete projected path forward.

\section{Entering the River}

The purpose of this paper is to analyse the shifting use of GIS in our ongoing research project. However, contextualising the study itself is important in order to understand the waters we are entering. Although the details will be expanded upon later in the paper, we provide a brief overview of the problem, the participants, and the planned goals of the study here-as an entry point to the analysis that follows.

This paper stems from a research project that sought a deeper understanding of how students from nondominant populations experience the spaces of a predominantly white, private university located in Southwestern United States. Nondominant, according to this study, includes students who fall outside the dominant descriptors (white, cisgender, heterosexual) of the student population (see Scheurich \& Young, 1997). Because we are cautious to avoid binary descriptors that further lift the dominant group, we use the term students of colour rather than nonwhite to describe the potential participants. These students' voices have often been silenced on campus, and this study sought to provide an outlet for their voices to be amplified. As the study progressed, the use of GIS to visually map the participants' experiences added another rock in our river, disrupting the anticipated flow of data, analysis, and representation. More specifically, disruptions began to build slowly from participants' and critical scholars' feedback, followed by our own conversations and reflections. Given that the study is still unfolding, the analysis and findings of this paper focus on these disruptions before continuing downstream. In the Embracing Disruptions section of the paper, we discuss these disruptions in more detail, analysing how and when to use a map as object in participatory research projects.

\section{Looking Upstream}

We enter this analysis midstream. The project is neither just beginning nor nearing completion. Standing on a rock in the middle of the river, we look upstream. Where has this project come from? Who has done this work before us, and what was our plan that brought us to this point? In order to take the reader through the evolution of our project thus far, we first compile a literature review of recent studies to provide historical context for GIS bringing in the theoretical tenets of the study, and we then outline our plan for the project as originally envisioned.

\section{Literature Review}

Geographic information systems (GIS) are computerised systems that allow users to electronically tag geographic locations with various information (Pacheco \& Velez, 2009). Maps can then be constructed for visual representation. Not intended to be an exhaustive representation of the uses of GIS, this review considers GIS as a research tool within YPAR, intended to value historically marginalised voices of students through visual representations of their experiences, oppressions, and aggressions. Important to the study at hand, concepts are also drawn from both new materialism and spatial theory as a means to question how GIS is traditionally used, and to posit possibilities for future iterations.

\section{Mapping technologies}

A healthy body of research and literature supports the use of GIS to inform and direct action in geography and urban planning (Elwood \& Mitchell, 2013; Thatcher, 2013; Wyly et al., 2012). In the broader field of geography, GIS has been widely used to map demographic and statistical data (Pacheco \& Velez, 2009). Traditional uses of geographic mapping with GIS are varied and include such 
wide uses as mapping universities degree programmes (Malhotra \& Vlahovic, 2011), mapping historic artefacts (Xing, Chen, \& Zhou, 2015), and planning community interventions (Smith \& Miller, 2013)see Bodenhamer, Corrigan, \& Harris (2010) or Hankins (2014) for more complete histories of GIS.

Mapping technology has also been included in community engagement projects and sites of activism (Elwood \& Mitchell, 2013; Foth, Bajracharya, Brown, \& Hearn, 2009), leading to a new form of visual politics (Miller, 2012; Rubel, Hall-Wieckert, \& Lim, 2016; Segel \& Heer, 2010; Wyly et al., 2012). Scaled representation of the community has helped stakeholders understand political implications for their community in a broader context (Helfenbein \& Buendia, 2017). For example, Smith and Miller (2013) used experts to map their city, and community members participated in making decisions for city planning based on the maps. The planning committee, in turn, learned more about the needs of the community based on race, power, and poverty due to gentrification.

Thus, voices, that have been historically silenced, may have the power to direct the way race, power, and privilege are discussed and delivered, impacting practices and policies. These maps can be presented to policy-makers and urban planners to create more equitable housing policies (Wyle et al., 2012), to protect or build green spaces (Rubel et al., 2016), to make public transportation more accessible (Soja, 2010), to understand the flow of resources (Burke, Greene, \& McKenna, 2016; Miller, 2012), or to plan public transportation (Foth et al., 2009).

Researchers using GIS also recognise the possibility to misunderstand or misuse information. Maps can be created and read differently through (un)intentional inclusion of information that reifies or contradicts a dominant narrative (Johnson, 2007; Rubel et al., 2016; Thatcher, 2013). Maps have had both legal and institutional effects contribute to the current racially scaled economy (Wyly et al., 2012). For example, mapping crime rates has been used to label neighbourhoods, predominantly neighbourhoods populated by people of colour, as dangerous, thus discouraging business investment and contributing to fewer housing opportunities (Wyly et al., 2012). Compounding these cycles of economic oppression, financial institutions targeted these same communities with high interest mortgage "opportunities." Wyly et al. (2012) stated that these "predatory home-financing schemes were perfected in subaltern America, among the people and places marginalised by social relations of class, race/ethnicity, gender, and metropolitan spatial restructuring" (p. 572). Understanding that widely accessible data may increase the risk to label neighbourhoods, reify stereotypes, and increase gentrification and displacement (Smith \& Miller, 2013), researchers can intentionally discuss the power of maps and the variables included or excluded with the goal of increased critical citizenship and agency (Rubel et al., 2016).

As we mention above, in considering GIS with(in) a critical YPAR framework, we see this work in line with research that challenges power structures, using GIS with students in participatory research to analyse social and cultural activities. These social and culture activities relate to the lives of students inside and outside the classroom, and educational researchers have begun to recognise the importance of geospatial analysis, using GIS as critical pedagogy (Rubel et al., 2016). Pacheco and Velez (2009) explained that:

Critical pedagogy is a field of study that looks at the social, political, and cultural context in which classroom learning operates, making an important connection between the teaching and learning that happens in the classroom and the dynamics of power and socialization that operate on a societal level. (p. 277)

Critical pedagogy has the potential to cross with the use of GIS tools for mapmaking in classrooms. For example, an after-school elementary programme in Los Angeles used mapping technologies aimed at 
"helping students reflect and respond to different dynamics in their lives-both in and out of school" (Pacheco \& Velez, 2009, p. 295). The students used GIS to layer photos, videos, sound recordings, and drawings of their own special places. Through discussion and analysis, they remapped their spaces as the community "ought to be" and then presented their ideas to parents, administrators and community members (Pacheco \& Velez, 2009, p. 297). In communities and in classrooms, maps offer a snapshot of human experience in spatial terms and, in doing so, concretise the complicated relationship between discursive and material practices of race, gender, and privilege. Therein lies the hope that maps can inspire conversation and spark change.

\section{GIS in youth participatory action research (YPAR)}

Centring on the participation of youth or students in the research process, YPAR researchers look for ways in which their work will "move beyond simplistic explanations, descriptions, and predications of youth behavior ... to both inform and inspire" (Ginwright, 2010, p. 20). YPAR projects open up possibility for conversation, understanding, and sustainable change (Burke et al., 2016; Smith \& Miller, 2013).

Students provide essential information in the way schools impact them both directly and indirectly. YPAR offers a framework for research that values that knowledge (Burke et al., 2016; Cammarota, Romero, \& Stovall, 2014; Evans, 2016). Partnering with youth, whose voices are traditionally marginalised, not only values their understanding and experiences but provides opportunity to create a counter narrative. Students have the "capacity to dream and imagine a new way of living" (Ginwright, 2010, p. 51), rubbing up against the dominant narrative of school settings. As a mobile technology, GIS is a potentially powerful tool in YPAR projects that seek to put meaning-making and representation in the hands of the student, and create a synergy between action, reflection, and the hope of possibility (Johnson \& Morris, 2010,). For example, Fine et al. (2005) listened to and documented the stories of students to understand and discuss how "deeply historic inequities are woven into the fabric of U.S. public education" (p. 10). Rubel et al. (2016) used GIS with high school math students to map two opposing neighbourhoods with foreclosures, liquor stores, community centres, and libraries, and considered the meaning demonstrated in the inequality of spaces. These students then designed parks and bike paths for their neighbourhood (Rubel et al., 2016).

University faculty use GIS with students outside the field of geography to promote critical thinking skills, community work, and hands-on learning (Malhotra \& Vlahovic, 2011; Pacheco \& Velez, 2009). Hankins (2014) cited several examples of partnerships between university faculty and students using visual mapping technologies. For example, students marked 19th century periodical presses as well as the spread of the railroad from 1840-1870 to connect patterns of transportation with spread of information (Hankins, 2014).

\section{Spatial theory}

The spaces in which we live, work, and play affect our lives both positively and negatively (Soja, 2010), and GIS provides a way to visually convey relational meaning of spaces. Space and place are terms used in a variety of disciplines and contexts, so drawing a distinction between them is important to move forward in analysis. Considering that we are spatial beings within physical spaces, place is constructed meaning within those spaces. These places of meaning are a crossing of "discursive, interpretive, lived and imagined practices" (Helfenbein, 2006, p. 92). Spaces are made up of places with socially created, accrued meaning (Rubel et al., 2016). Places support the formation of identity, security, and belonging within spaces (Ellis, 2004, p. 86). Connecting with ideas of new materialism, spatial researchers see this formation as fluid rather than fixed. "Forces of economic, social, and cultural practices work on both the inhabitants of the place and work to form the place itself" (Helfenbein, 2010, p. 306). Humans 
impact and are impacted by the social relations in those spaces (Nieuwenhuis, 2016). Within lived spaces, bodies negotiate gender identities, power, and social relations based on age, gender, and race (Fairclough, Graham, Lemke, \& Wodak, 2004). Looking at the politics of spaces helps policy makers, community members, educators, and students understand oppressive cycles of policies imposed on communities (Lipman, 2012).

Identity construction as a social process is complex and complicated as detailed by other social theorists (Butler 2015; Fanon, 1967; Foucault, 1995; Hall, 2006) and, while spatial theory is not a prescriptive theoretical grounding, to consider space in relation to other theories involving identity offers a fuller epistemological and ontological picture (Soja, 2010). The multilayered and scaled complexity of spatial analysis (Helfenbein \& Buendia, 2017) further demonstrates the need for visual representation in participatory projects. In other words, spatial theory offers a glimpse into the complicated relationships between humans and their surrounding contexts. GIS could be first, a snapshot of those relationships and second, a conversation starter for further investigation and action.

\section{New materialism}

The ability of GIS to represent snapshots of fluid meaning supports ideas born out of the scholarship often referred to as new materialism. While there are many divergent ideas within this theory, most contend that the material world is not lifeless soil but something more dynamic (see Coole \& Frost, 2010a; Dolphijn \& van der Tuin, 2012; Huddleston, 2016; Lather \& St. Pierre, 2013). For our purposes, we turn to Barad (2003) who linked quantum physics with critical social theory, shifting the focus of inquiry away from the material and discursive existing at opposing ends of a dichotomy. Instead, maps, our focus of inquiry, are objects of analysis that are linguistically and materially entangled. Furthermore, she posited that such entanglements are hyper-contextual, resulting in a continual state of becoming. In other words, the material does not construct our reality any more than the discursive defines us socially-instead, it is how the relationship morphs, depending on the context (Huddleston, 2016).

When objects, words, people, or places come together, they make something altogether new (Deleuze \& Guattari, 2014). Barad (2003) termed this continuum of becoming, "onto-epistem-ology" (p. 829). For our purposes, we apply Barad's onto-epistem-ology to mean the ability to use maps as meaningmaking of marked experiences in time and space, with the understanding that this is not a static representation of meaning but a point in an evolving state. Any static method used to represent reality, whether linguistically, discursively, or culturally construed, distorts reality in some way (Coole \& Frost, 2010b). Researchers acknowledge the material experiences of participants while anticipating that these realities flow and change (Voithofer, 2013). Yes, GIS is a tool to powerfully represent data and effect change by demonstrating how the spatial affects people, and new materialism forces us to concede GIS visual data as already obsolete. The relational ontologies of new materialism disrupt the static representation of a fixed point on a map, bringing the geography and biology of social life into conversation "in a discipline which for a long time intentionally decided to ignore the issues arising from this connection" (Nieuwenhuis, 2016, p. 302).

To understand and represent individual agency within spaces, researchers with a material lens look at more than language. Matter and language is this "entangled assemblage" within the process of constructing meaning (Evans, 2016, p. 67). Maps, spatial thinking, and GIS come together to represent these interactions spatially. This understanding is not just theoretical but also political because these spaces can either be seen as a "relational place for change or as a force of stability " (Nieuwenhuis, 2016 , p. 300). Seeing the subjectivity, and also the ability to act within spaces, provides context for critical examination of how we view our individually lived lives within normative measures, as well as the actions we daily accept or challenge. Ultimately, new materialism demands users of GIS eschew 
static representations of matter and language relationships. Such a demand challenges how maps have traditionally been used in GIS studies. In other words, GIS is not an endpoint, but another rock in the river.

\section{Projected Plan}

This project was intended to gather a deeper understanding of the experiences of students selfidentifying with a nondominant population on a college campus. These voices have been historically silenced. Prompted by a social media surge about what it means to identify as a person of colour on campus, the concerns of racial prejudice and bias on this campus received both national and local attention, stirring a backlash from the mainstream student population. As critical researchers, our own backgrounds and interests merged as we considered using GIS as a research tool in a YPAR project valuing spatial knowledge. At the time of writing, the study is still evolving. Collaborative reflection among researchers, colleagues, and potential participants has allowed the study to move, pause, and move again in unexpected directions. The focus in this section is the evolution in both thinking and action. That being said, some foregrounding of the project seems necessary for understanding this evolutionary process.

\section{Participants and setting}

This study is situated in a midsize, private university within the boundaries of a large city in Southwestern United States. The student body roughly consists of 10,000 students of whom $73.3 \%$ are white, $60.1 \%$ are female, and $84.5 \%$ are between the ages of 18 and 24 years. The area surrounding the university is a mixture of small chain and privately owned restaurants and bars, a large chain grocery store, and residential housing. With the estimated yearly cost of attending the university at slightly over $\$ 60,000$ to attend full time, the population of the university is predominantly from middleand upper-income families.

Understanding the power of visual representation, the study intended to recruit up to 20 students from marginalised groups on campus and attempt to better understand their experiences through spatial consideration. We base our identification of marginalisation on the body of research that demonstrates how our education systems are built on a legacy of oppressing identities that fall outside of the dominant hegemony (see Anyon, 1997, 2005; Fasching-Varner, Albert, Mitchell, \& Allen, 2015; Kozol, 1991; Lareau, 2003; Tatum, 1997; Watkins, 2001; Winfield, 2007; Wozolek, Wootton, \& Demlow, 2017). Students were recruited from organisations who share a common interest in improving marginalised populations' equality of access and experiences in the campus community. We used snowball sampling to recruit participants through connections to other community members who are knowledgeable about the experiences of marginalised populations on campus (Neuman, 2006). This first attempt at recruiting resulted in a small return of fewer than five students, which created a small rock or disruption to our planning worthy of further consideration. These ideas will be discussed in more detail later.

\section{Procedure}

The research process was intentionally designed to be fluid, following a YPAR methodology to support the needs and desires of participants. With that in mind, we present the original envisioning of the project (following three phases), the disruption in the plan and why, and how we are proceeding next.

\section{Stage One: Informational meetings.}

An e-mail was sent to the lead contact of groups formed on campus around ideas of race, gender, or equity. This e-mail provided an overview of our study and requested time during their next group 
meeting for a brief presentation. The presentation was planned to present our project's purpose and process to the group members.

\section{Stage Two: Focus groups.}

The participants would participate in a semi-structured focus group serving two purposes: to give participants specific information about mapping technology, and to allow participants to guide what experiences to map, to define the mapping locations, and to create a project timeline.

\section{Stage Three: Collecting and analysing geographic data.}

The researchers and participants would meet to discuss the data collected. The researchers planned to show the mapped experiences and lead discussion. Discussion may lead to further action. This stage of the research will support the validity of the data through member checking as the researchers challenge their own conclusions, conceptions, and understanding (Erlandson, 1993). This semistructured focus group would use the following questions to guide discussion:

- What surprised you about the data?

- What commonalities do you see?

- Where do you see diverse experiences?

- What thoughts do you have moving forward?

- What ideas do you have in terms of next steps?

Data analysis is intended to be an ongoing process throughout the study, creating a spiral of data that informs the research process (Creswell, 2013). Although we, as researchers, plan to code data, the participants' discussion will help guide us, challenging our own conclusions, conceptions, and understanding (Erlandson, 1993), valuing the participant as knowledge-owner and resisting the trap of researcher-as-rescuer (Lather, 1986). Again, this was the plan as intended from the beginning stages of the research. However, at the time of writing, the study itself is between Stage One and Stage Two. This pause is due to several disruptions that came from participant and scholarly feedback, followed by reflective discussion. Like a small rock lodged in a river bed, taken alone, any one of these disruptions may not materially change the flow of our research. However, stacking rock upon rock, sediment begins to accumulate, and the flow of the river changes.

We began the study as planned in Stage One, sending an e-mail to the lead contact of groups formed on campus around ideas of race, gender, or equity. This e-mail provided an overview of our study and requested time during their next group meeting for a brief presentation. However, with these disruptions, we did not proceed to Stage Two. The following analysis documents this journey.

\section{Embracing Disruptions}

The stream peacefully winds its way down the mountainside, widening and narrowing, picking up living and nonliving passengers, leaving behind nutrients, providing life in a balanced ecosystem. A collected mass of rocks now disrupts its path, but the disruption is not a detriment. Contrary to the negative connotations of the word "disruption," this mass adds difference, beauty, varied motions, sounds, splashes, currents, and swirls of energy. Such is the case with our research. Research is discussed among scholars, planned with partners, supported with prior literature. It is perfectly laid out as it moves toward implementation, and yet the plan is obsolete when it is implemented. As we continued to move with the work through recruiting, writing, reflecting, and discussing with other researchers and participants, we began to see a formation of rocks building that changed the direction of our 
research. This gathering of rocks was not made up of one event but a gathering of ideas. This became our data for analysis on how to proceed in research, loosely placing these disruptions into three themes: implications, boundaries, and cautions.

\section{Implications}

Education researchers have been slow to use mapping tools to engage in conceptual understanding of space (Tefera, Aguilar, Artiles, Voulgariges, \& Velez, 2017). More common is "the practice of mapping just for the sake of mapping," calling for an urgency "to use map-making beyond visual representations of quantitative data because maps reveal deeply rooted educational inequities" (Tefera et al., 2017, p. 203). From our beginning conversations, we knew we wanted this project to move toward change. Based on our theoretical frames discussed earlier and our conversations with potential participants, we did not want to stop with a map. We saw the potential of using GIS as a fluid and incomplete representation of a moment in time and space that is also a path moving toward something else, so we continually circled back around to: "So what?" The work should be purposeful, rather than "merely showing the increasing" problems or experiences of marginalised groups (Hierofani, 2016, p. 2078). And in doing so, researchers need to rethink the epistemological and methodological implications of their approach to mapmaking (Tefera et al., 2017). So what might that look like in this project?

Though the project is still forming, this slow (and at times painful) process of recruiting, listening, and changing directions contributes to the understanding of partnerships in research and the practical place GIS might have in education research. Although the goal was never to end with the map but to move toward a larger trajectory of change, we originally envisioned the map as a visual representation that might contradict the dominant narrative of college experience: that might increase understanding. For example, Pacheo and Velez (2009) suggested creating counter-maps that represent the world from alternative perspectives. However, when discussing the project with potential participants and other critical researchers, it became clear that we would have to consider structural and representational limitations of GIS as well as additional ethical concerns. In other words, perhaps a map demonstrating racial discrimination on campus should not be shared with the general public. Maybe it should only be used with participants.

Considering the map as an object that conveys meaning, we had to recognise not only the agency of the participants but the agency of the object itself. Yes, this mapping of experiences has the potential to be a powerful source of information, and it also has the power to label places as safe, dangerous, racist, oppressive, accepting, and so forth. These decisions were not ours to make as researchers but needed to be placed in the hands of the participants.

We let go of our plan to use a map as a visual tool to inform those in positions of power and privilege in order to protect the spaces where students felt safe. We were concerned that displaying maps to a broader population might risk exposing those safe spaces. For our project, this meant using the maps as a means to find collective power within the group of participants. We changed our map from a tool that informs a broader population to a tool that informs participants in order to plan action around collective ideas.

\section{Boundaries}

Through the beginning stages of implementation, we also found a need to place boundaries around our research that we originally tried to avoid. Participatory projects seek to break up the binary between local and scientific knowledge so that mapping decisions are put in the hands of stake holders (Sletto, Munoz, Strange, Donoso, \& Thomen, 2010). That being said, we wanted to let participants define what would be mapped, how it would be mapped, and how the map would be used. However, 
after meeting with potential participants, we learned that the project needed some bounding and defining in order to successfully recruit participants.

Feedback from potential participants told us that the lack of detail failed to draw students into our study, and the potential workload discouraged participation. With that in mind, we changed the plan. We gathered data from a broadly dispersed short survey and plan to map the information and bring it to a focus group of students. The focus group would then generate next steps. This, for us, has been a powerful realisation, reminding us of the weight we are asking students to carry.

\section{Cautions}

When we entered the river, we planned for students to map their campus where they experienced safety, joy, camaraderie, as well as places where they experienced oppressions, aggressions, or exclusions. This map was intended to be both informative for participants to see connections within their shared experiences, as well as a means of informing the larger campus community. The process of finding research participants proved difficult and largely unsuccessful, forcing us to reevaluate what we were asking participants to do and what risks were entailed. Gathering information from the broadly dispersed survey, and then using a focus group to discuss the maps and to decide further action, now leads to three main concerns: reifying otherness, oversimplifying identity, and explicitly addressing assumptions.

\section{Reifying otherness}

This project intentionally seeks to disrupt binary language of positivist research, thus, the focus on spatial theory and new materialism scholarship. However, this can present a particular challenge within GIS studies. Although GIS studies have the potential to represent a fluidity through constant access to technology that written reports often lack, they are still bounded by restrictions of language and symbols, as well as technical and financial resources. A map, relied upon for accuracy in terms of direction and location, is a definitive symbol of capital " $T$ " truth. As such, geographic boundaries, both physically and politically constructed, powerfully separate and shape the identity of those bounded by being located or represented on a map. As we hope to highlight marginalised populations and narratives that push against normalising, we risk distinguishing these ideas and bodies against the dominant, reifying the otherness we seek to deconstruct (Nightingale, 2011). Seeking to disrupt socially constructed binary labels brings into question the way we use language, symbols, and participant knowledge. Leaning on the work of critical feminist geographers, we might navigate this challenge by situating the research within multiple perspectives, or intersectionality (Nightingale, 2011). Rather than labelling experiences according to gender, sexuality, or race only, we should point to an intersection of identities, looking for connections rather than separations (Nightingale 2011; Silvey 2004)-resisting generalisations or fixing characteristics (Voithofer, 2013). For our work, this may mean broadening the participant selection and being deliberate in recruitment to include perspectives that cross borders of socioeconomic status, age, race, sexuality, and so forth.

\section{Oversimplifying identity}

Identities are a complex intersection of our various places in the world; they are fluid and shifting within contexts and relationships (Valentine, 2007). Lather (1986) explained that this simplistic view of subjectivity risks feeding into "theory that is reinforced by experience that is conditioned by theory" (p. 261). Bodies are subject to cultural normativity but also push against it within lived spaces to negotiate gender identity, power, and social relations based on age, gender, and race (Fairclough et al., 2004; Nieuwenhuis, 2016). Any attempt to describe subjectivity will always be one of incompleteness because bodies are not completely subjected, nor autonomous, in the world. We both 
shape and are shaped by the social relations within the places we live, work, and play (Massey, 1994; Soja, 2010).

A fractured analysis of the stories of lives takes time to understand and to share. These glimpses of experience do not provide a broad view across contexts. Honouring individual experiences is important in this research, and we also want to create a common narrative that is useful as a catalyst for change. Some scholars critique multiplicity and radical contextuality, fearing that a fracturing of voice would be counterproductive to change (Butler, 1993). Critical geography helps to make sense of this quandary by considering scale within spatial and gendered scholarship.

Although experiences of bodies and souls that reflect counter-cultural ideas will differ, this research could emphasise the connection to other bodies within communities. That connection, when made on a larger scale, can create a common narrative and impact social and political change (Butler, 1993; McLaren, 2002) with a message of unity, undergirding our decision to use the map as a discussion point in future conversations with participants and not as findings to be presented to the larger campus community.

\section{Recognising assumptions}

Participants and researchers come with assumptions wrapped in powerful collective memories (Winfield, 2007). Acknowledging them is important, but we also need to look for disturbances and consider the impact of those disturbances. As Tsing (2015) pointed out, disturbances open up discussion and force consideration of another's point of view because "with disturbance, this is always a problem of perspective based, in turn, on ways of life" (p. 161). To understand disturbance, we listen closely to the voices of each other (Winfield, 2007). As researchers we recognise that we are not the only ones bringing assumptions to the work. Researchers and participants have alternative experiences and therefore alternative readings on campus life. These differences may provide more disruptions that move and change our research together.

\section{Looking Downstream}

Standing on the boulder and looking downstream, where does the project move from here? Valuing the voice of youth is important and the power of spatial visual representation is undeniable, so we continue to look for ways to recognise both. We want to fight against hegemony's ability to carve up spaces to disenfranchise populations by valuing the interconnectedness of spaces on a larger scale (Burke et al., 2016). This might mean that the map is not shared as a way to inform a dominant population, but as a means to find and celebrate resistance and unity within and across borders. Not that our intentions have changed, but noticing disruptions has refocused our attention. We have always intended for our research to create unity, systems of support, examination of structures of power. This reminds us, as researchers, that the map as object is only a tool, a process, a story, rather than a static end result.

Other critical researchers have provided examples of possibilities. This might culminate in walking with students through and around campus spaces, listening to their stories and experiences, encouraging them to take photographs and then turning those stories and documents into a living map. Burke et al. (2016) used this method in a YPAR study and then, according to the insistent voices of the students, persistently kept the power of change in the hands of youth. Ares (2017) conducted walking interviews and then created a Google Earth tour of the route. Moving forward, in order to protect the safe places of resistance, the visual information represented in this study is most beneficial when used to mobilise participants towards action - to allow participants to decide the next step. 


\section{Conclusion}

Valuing spatial thinking and material ways of being and knowing opens new possibilities to imagine what education research might look like, using tools that emphasise spatial and material representation. In YPAR projects, we must deeply consider: "What are we asking youth, who may already be facing an inequitable amount of obstacles, to do for us?" Their shoulders are already carrying the burden of informing, awakening, and enlightening, and asking them to expose their safe spaces might jeopardise how and where they lay such burdens down. Burke et al. (2016) stated:

It is important, we argue, to not only hear student voices but also prepare them to become critical, independent thinkers, who can use multiple literacies as affordances for creating changes that help nourish them. This means fundamentally rethinking how as educators we listen to and walk with youth as they reframe the ways in which we might use public parks, neighborhoods schools, community centres, and sidewalks as pedagogical and political spaces. (p. 143)

These words provide a way to navigate an ever-changing river rather than being washed ashore in uncertainty. For this project, it reminds us to remember that our goal is to extend a bridge of possibility from what we know to what we do not yet understand. The work is made worthy as we seek to honour the knowledge decisions and connections of souls labelled as "the other."

Not bound by but always grounded in historically linguistic constraints, critical researchers look for ways to "give equal footing to the material and the discursive" (Voithofer, 2013, p. 529). Research tools like GIS begin to give way to this equal footing but, paradoxically, only if researchers are willing to question and problematise the very tools themselves. This paper proposes a version of GIS that emphasises participant control, values participant knowledge and time, and also seeks to protect and not expose participant vulnerability. Possibility for social change, then, will begin with the realisation of common experiences and agency through discussions around the visual mapping of student experience. In other words, GIS, and therefore maps, help researchers and participants to visualise what social change could look like, but it, in and of itself, is not a guarantee or a marker of social change. By relying on both new materialism and spatial theory as theoretical foundations, GIS has the potential not as a tool that excludes other ways of collecting, interpreting, and representing data, but as one that expands the researchers' tools to help students understand their own experiences, inequalities, and exclusions, and to visually represent those experiences for collective understanding and action. GIS has the ability to embrace disruptions, to move downstream in a new, more fully democratic way of researching, living, and being together.

\section{References}

Anyon, J. (1997). Ghetto schooling: A political economy of urban educational reform. New York, USA: Teachers College Press.

Anyon, J. (2005). Radical possibilities: Public policy, urban education, and a new social movement. New York, USA: Routledge.

Ares, N. (2017). Story maps as convincing representations of claims to space. In N. Ares, E. Buendia, \& R. Helfenbein (Eds.), Deterritorializing-reterritorializing: Critical geography of educational reform (pp. 109-124). Rotterdam, Netherlands: Sense.

Barad, K. (2003). Posthumanist performativity: Toward an understanding of how matter comes to matter. Signs, 28(3), 801-831. doi:10.1086/345321

Bodenhamer, D. J. Corrigan, J. \& Harris, T. M. (2010) The spatial humanities: GIS and the future of humanities scholarship. Bloomington, USA: Indiana University Press. 
Burke, K. J., Greene, S., \& McKenna, M. K. (2016). A critical geographic approach to youth civic engagement: Reframing educational opportunity zones and the use of public spaces. Urban Education, 51(2), 143-169.

Butler, J. (1993). Bodies that matter. New York, USA: Routledge.

Butler, J. (2015). Gender trouble: Feminism and the subversion of identity. New York, USA: Routledge.

Cammarota, J., Romero, A., \& Stovall, D. (2014). Raza studies: The public option for educational revolution. Tucson, USA: University of Arizona Press.

Coole, D. H., \& Frost, S. (2010a). New materislisms: Ontology, agency, and politics. London, UK: Duke University Press.

Coole, D. H., \& Frost, S. (2010b). Introducing the new materialisms. In D. H. Coole \& S. Frost (Eds.), New materialisms: Ontology, agency, and politics (pp. 1-46). London, UK: Duke University Press.

Creswell, J. W. (2013). Qualitative inquiry and research design: Choosing among five approaches. Newbury Park, USA: SAGE.

Deleuze, G., \& Guattari, F. (2014). What is philosophy? New York, USA: Columbia University Press.

Dolphijn, R., \& van der Tuin, I. (2012). Interview with Karen Barad. In R. Dolphijn \& I. van der Tuin (Eds.), New materialism: Interviews \& cartographies (pp. 48-70). Ann Arbor, USA: Open Humanities Press.

Ellis, J. (2004). Researching children's place and space. Journal of Curriculum Theorizing, 20(1), 83-92.

Elwood, S., \& Mitchell, K. (2013). Another politics is possible: Geogeographies, visual spatial tactics, and political formation. Cartogra phica: The International Journal for Geographic Information and Geovisualization, 48(4), 275-292. doi:10.3138/carto.48.4.1729

Erlandson, D. A. (1993). Doing naturalistic inquiry: A guide to methods. Newbury Park, USA: SAGE.

Evans, K. (2016). Beyond a logic of quality: Opening space for material-discursive practices of 'readiness' in early years education. Contemporary Issues in Early Childhood, 17(1), 65-77. doi:10.1177/1463949115627904

Fairclough, N., Graham, P., Lemke, J., \& Wodak, R. (2004). Introduction. Critical Discourse Studies, 1(1), 1-7. doi:10.1080/17405900410001674489

Fanon, F. (1967). Black skin, white masks. New York, USA: Grove Press.

Fasching-Varner, K. J., Albert, K., Mitchell, R., \& Allen, C. (Eds.). (2015). Racial battle fatigue in higher education: Exposing the myth of post-racial America. Lanham, USA: Rowman \& Littlefield.

Fine, M. J., Bloom, A., Burns, L., Chajet, M., Guishard, Y, Payne, T., . . Torre, M. (2005). Dear Zora: A letter to Zora Neal Horston 50 Years after Brown. Teacher College Record 10(7): 496-528.

Foth, M., Bajracharya, B., Brown, R, \& Hearn, G. (2009). The second life of urban planning? Using geography tools for community engagement. Journal of Location Based Services 3(2): 97-117.

Foucault, M. (1995). Discipline and punish: The birth of the prison. New York, USA: Vintage Books.

Ginwright, S. A. (2010). Black youth rising: Activism and radical healing in urban America. New York, USA: Teachers College Press.

Hall, S. (2006). Cultural identity and diaspora. In B. Ashcroft, G. Griffiths, \& H. Tiffin (Eds.), The postcolonial studies reader (pp. 435-438). New York, USA: Routledge.

Hankins, G. A. (2014). Visualizing modernist magazines with Geographic Information Systems (GIS): New approaches in the spatial humanities. The Journal of Modern Periodical Studies, 5(1), 69-93.

Helfenbein R. J. (2006). Economies of identity: Cultural studies and a curriculum of making place. Journal of Curriculum Theory, 22(2), 87-100. 
Helfenbein, R. (2010). Thinking through scale: Critical geography and curriculum spaces. In E. Malewski (Ed.), Curriculum studies handbook: The next moment (pp. 304-317). New York, USA: Routledge.

Helfenbein, R. \& Buendia, E. O. (2017). Critical geography of education: Theoretical framework. In N. Ares, E. Buendia \& R. Helfenbein (Eds.), Deterritorializing-reterritorializing: Critical geography of educational reform (pp. 27-40). Rotterdam, Netherlands: Sense.

Hierofani, P. Y. (2016). Gender, work, and migration: Reflections on feminist geography, contributions, and challenges. Environment and Planning, 48(10), 2076-2080. doi:10.1177/0308518X16659480

Huddleston, G. (2016). The zombie in the room: Using popular culture as an apparatus. In N. Snaza, D. Sonu, S. Truman, \& Z. Zaliwska (Eds.), Pedagogical matters: New materialisms and curriculum studies (pp. 109-122). New York, USA: Peter Lang.

Johnson, M. L. (2007). Seeing through maps: Many ways to see the world. Cartographic Perspectives, (56), 60-62. doi:10.14714/CP56.31

Johnson, L., \& Morris, P. (2010). Towards a framework for critical citizenship education. The Curriculum Journal, 21(1), 77-96.

Kozol, J. (1991). Savage inequalities: Children in America's schools. New York, USA: Crown Pub.

Lareau, A. (2003). Unequal childhoods: Class, race, and family life. Berkeley, USA: University of California Press.

Lather, P. (1986). Research as praxis. Harvard educational review, 56(3), 257-278.

Lather, P., \& St. Pierre, E. A. (2013). Post-qualitative research. International Journal of Qualitative Studies in Education, 26(6), 646-657. doi:10.1080/09518398.2013.788754

Lipman, (2012). Neoliberal urbanism, race, and equity in mathematics education. Journal of Urban Mathematics Education, 5(2), 6-17.

Malhotra, R., \& Vlahovic, G. (2011). GIS educational opportunities at historically black colleges and universities in the United States. Southeastern Geographer, 51(3), 443-456.

Massey, D. B. (1994). Space, place, and gender. Minneapolis, USA: University of Minnesota Press.

McLaren, M. (2002). Feminism, Foucault, and embodied subjectivity. Albany, USA: State University of New York Press.

Miller, P. M. (2012). Mapping educational opportunity zones: A geospatial analysis of neighborhood block groups. The Urban Review, 44(2), 189-218.

Neuman, W. L. (2006). Social research methods: Qualitative and quantitative approaches (5th ed.). Boston, USA: Pearson, Allyn \& Bacon.

Nieuwenhuis, M. (2016). The emergence of materialism in geography: Belonging and being, space and place, sea and land. Social Science Information, 55(3), 300-320. doi:10.1177/0539018416638949

Nightingale, A. J. (2011). Bounding difference: Intersectionality and the material production of gender, caste, class, and environment in Nepal. Geoforum 42(2). 153-162.

Pacheco, D., \& Velez, V. N. (2009). Maps, mapmaking, and critical pedagogy: Exploring GIS and maps as a teaching tool for social change. Seattle Journal for Social Justice, 8(1), 273-302.

Rubel, L., Hall-Wieckert, M., \& Lim, V. (2016). Teaching mathematics for spatial justice: Beyond a victory narrative. Harvard Educational Review, 86(4), 556-579. doi:10.17763/1943-5045-86.4.556

Scheurich, J. J., \& Young, M. D. (1997). Coloring epistemologies: Are our research epistemologies racially biased? Educational Researcher, 26(4), 4-16. 
Segel, E., \& Heer, J. (2010). Narrative visualization: Telling stories with data. IEEE Transactions on Visualization and Computer Graphics, 16(6), 1139-1148. doi:10.1109/TVCG.2010.179

Silvey, R. (2004). Power, difference and mobility: Feminist advances in migration studies. Progress in Human Geography 28(4). 490-506.

Sletto, B., Munoz, S., Strange, S. M., Donoso, R. E., \& Thomen, M. (2010). Journal of Latin American Geography, 9(3), 111-135.

Smith, R., \& Miller, K. (2013). Ecocity mapping using GIS: Introducing a planning method for assessing and improving neighborhood vitality. Progress in Community Health Partnerships: Research, Education, and Action, 7(1), 95-106. doi:10.1353/cpr.2013.0000

Soja, E. W. (2010). Seeking spatial justice (ProQuest ebrary). Retrieved from http://site.ebrary.com.ezproxy.tcu.edu/lib/tculibrary/detail.action?doclD=10400723

Tatum, B. D. (1997). "Why are all the Black kids sitting together in the cafeteria?" and other conversations about race. New York, USA: Basic Books.

Tefera, A., Aguilar, C. R., Artiles, A. J., Voulgariges, C. K., \& Velez, V. (2017). Developing a critical space perspective in the examination of the racialization of disabilities. In N. Ares, E. Buendia \& R. Helfenbein (Eds.), Deterritorializing-reterritorializing: Critical Geography of educational reform (pp. 191-208). Rotterdam, Netherlands: Sense.

Thatcher, J. (2013). Avoiding the ghetto through hope and fear: An analysis of immanent technology using ideal types. Geojournal, 8(6), 967-980. doi:10.1007/s10708-013-9491-0

Tsing, A. L. (2015). The mushroom at the end of the world: On the possibility of life in capitalist ruins. Princeton, USA: Princeton University Press.

Valentine, G. (2007). Theorizing and researching intersectionality: A challenge for feminist geography. The professional geography, 59(1), 10-21.

Voithofer, (2013). Promiscuous feminism for troubling times. International Journal of Qualitative Studies in Education, 26(5), 524-539.

Watkins, W. H. (2001). The white architects of black education: Ideology and power in America, 18651954. New York, USA: Teachers College Press.

Winfield, A. G. (2007). Eugenics and education in America: Institutionalized racism and the implications of history, ideology, and memory. New York, USA: Peter Lang.

Wozolek, B., Wootton, L., \& Demlow, A. (2017). The school-to-coffin pipeline: Queer youth, suicide, and living the in-between. Cultural Studies $\leftrightarrow$ Critical Methodologies, 17(5), 392-398. doi:10.1177/1532708616673659

Wyly, E., Ponder, C. S., Nettling, P., Ho, B., Fung, S. E., Liebowitz, Z., \& Hammel, D. (2012). New racial meanings of housing in America. American Quarterly, 64(3), 571-604.

Xing, H., Chen, J., \& Zhou, X. (2015). A geoweb-based tagging system for borderlands data acquisition. International Journal of Geo-Information, 4(3), 1530-1548. doi:10.3390/ijgi4031530 